\title{
Effect of Storage Time and Gamma Irradiation on the Chemical Properties of Olive (Olea europaea) Oils
}

\author{
AL-BACHIR, M..$^{a^{*}}$ \\ ${ }^{a}$ Department of Radiation Technology, Atomic Energy Commission of Syria, Damascus, P.O. Box 6091, Syria \\ ${ }^{*}$ Corresponding author \\ ascientific@aec.org.sy
}

Received: 2 April 2017; Published online: 18 April 2018

\begin{abstract}
The objective of this study was to investigate the effects of gamma irradiation at doses of $0,1,2$ and $3 \mathrm{kGy}$, and storage time of olive fruits for 0,30 and 45 days on changes in chemical properties of olive oil during storage periods of 0,6 and 12 months. The initial acidity value (AV), peroxide value (PV), Thiobarbituric Acid (TBA), phenolic content, iodine value (IV) and saponification value (SV) of virgin olive oil obtained from olives fruits immediately after harvest (at day zero) were $1.04 \%, 3.06 \mathrm{mEqO}_{2}$ $\mathrm{kg}^{-1}$ oil, $0.025 \mathrm{mg}$ MDA kg-1 oil, $314.71 \mathrm{mg}$ gallic acid $\mathrm{kg}^{-1}$ oil, $93.38 \mathrm{gI}_{2} 100 \mathrm{~g}^{-1}$ oil and $194.88 \mathrm{mg}$ $\mathrm{KOH} \mathrm{g}^{-1}$ oil, respectively. In general, the AV and PV of olive oil was increased by gamma irradiation, while the phenolic and IV of olive oil was deceased by gamma irradiation and storage time. The TBA value and SV of olive oil was not significantly $(\mathrm{p}>0.05)$ changed by gamma irradiation.
\end{abstract}

Keywords: Olive oil; Gamma irradiation; Olive fruit storage; Oil storage; Chemical properties

\section{Introduction}

Virgin olive oil (VOO) is one of the essential elements of the Mediterranean diet. The nutritional value of olive oil arises from high levels of oleic acid and minor components, such as phenolic compounds (Artajo, Romero, Morello, \& Motilva, 2006).

In households and restaurants, olive oil is stored for various periods of time, under different temperature and light conditions depending on the consumption rate. It is well known that some factors affect oil properties. Among the factors that significantly influence the preservation of olive oil quality are the extraction methods, the packing materials and the storage conditions (Cecchi, Passamonti, \& Cecchi, 2010). Moreover, the storage conditions and the extractive technology cause further differences (Vekiari, Papadopoullou, \& Kiritsakis, 2007). Therefore, before consumption of the oil, its initial components and properties can change significantly in many different ways (Cecchi et al., 2010; Jenisová, Branisa, Jomová, \& Porubská, 2014). However, many aspects still require further investigation, due to the complexity and variable composition of olive oil. (Jenisová et al., 2014). This text describes some of them and shows a vision of research on olive oil for the near future, bringing together those aspects that are more relevant for better understanding and protection of this edible oil (Garcia-Gonzalez \& Aparicio, 2010).

Food irradiation is increasingly recognized as a method for reducing post harvest food losses, ensuring hygienic quality, and facilitating a wider trade in foodstuffs.

Irradiation can also slow down the ripening or maturation of certain fruits and vegetables (Sadecka, 2010). In general, any modifications caused by treatment with doses up to $10 \mathrm{kGy}$ are considered harmless to human health by WHO, 
FAO and IAEA (Hong, Kim, Cho, \& Park, 2010). The effect of irradiation on locally stored foods is of utmost importance and an insight into these aspects of storage will help in understanding the shelf life of foods as well as its effects on sensitive nutrients (Al-Bachir \& Zeinou, 2014). Very few studies have addressed the evolution of the quality parameters and shelf-life during irradiation and prolonged time. Even though it is well known that, in the traditional producing countries, in the better vintages, people usually purchase great amounts of olive oils which are then stored for years (Baiano, Terracone, Viggiani, \& Del Nobile, 2014). The present study investigated the changes of chemical parameters of olive oil from gamma irradiated and non-irradiated Kaissy cultivar, an important Syrian cultivar, stored after irradiation for 0,30 and 45 days at ambient temperature before extracting the oil, and during 12 months of olive oil storage.

\section{Materials and Methods}

The studied olive cultivar was Kaissy, the most widespread in Syria. The good quality olive fruits of that were mature and firm were harvested from the crop year $2008 / 2009$, from the trees grown in grove located in the countryside near Damascus (Deer Al Hajar, Syria), using conventional agriculture practices. The olive fruits were weighed according to the sampling plan and transferred into polyethylene pouches for irradiation. Each pouch of olive fruits $(1 \mathrm{~kg})$ was considered as a replicate. The samples were then divided into four groups: group 1 (control) and groups 2, 3 and 4 were irradiated with 1,2 and $3 \mathrm{kGy}$ of gamma irradiation.

\section{$2.1 \quad$ Irradiation process}

Samples of olive fruits were exposed to gamma radiation doses at $0,1,2$ and $3 \mathrm{kGy}$ in a ${ }^{60} \mathrm{CO}$ package irradiator (ROBO, Techsnabexport, Moscow, Russia). Irradiation was carried out in the stationary mode of operation with the possibility of varying dose rate (10.846 to 3.921 $\mathrm{kGy} \mathrm{h}^{-1}$ ) depending on the location and the distance from the source (10 to $40 \mathrm{~cm})$. The samples were irradiated in place (15 cm from source) with a dose rate of $9.571 \mathrm{kGy} \mathrm{h}^{-1}$. The irradiations were carried out at room temperature $(20-$ $25^{\circ} \mathrm{C}$ ) and atmospheric pressure. The absorbed dose was determined using alcoholic chlorobenzene dosimeter (Al-Bachir \& Zeinou, 2014).

\subsection{Oil extraction}

The oils from control and irradiated olive fruits were extracted from olives stored at ambient temperature for 0,30 and 45 days after irradiation using a mechanical and physical processes (Blatchly, Delen, \& O'Hara, 2014). Olive fruits were crushed with hummer crusher and slowly mixed for about $30 \mathrm{~min}$ at $27{ }^{\circ} \mathrm{C}$. Then, the past mixed was centrifuged at $3000 \mathrm{rpm}$ for 3 min without addition of water to extract the oil. Finally, the oils were decanted and immediately transferred into dark glass bottles and stored at room temperature $\left(20-25{ }^{\circ} \mathrm{C}\right)$. Chemical analysis of oils extracted from irradiated and nonirradiated olive fruit samples were performed immediately after irradiation, and after 6 and 12 months of storage.

\subsection{Determination of total phenol content of olive oil extracts}

Phenolic compounds were isolated from olive oil by a 3-time extraction of solution of oil in hexane with water mixture $(60: 40 . \mathrm{v} / \mathrm{v})$. The FolinCiocalteau reagent (Merck Schuchardt OHG. Hohenbrunn, Germany) was added to a suitable aliquot of the combined extracts, and the absorption of the solution was measured at 725 $\mathrm{nm}$ using UV-VIS spectrophotometer (PG Instrument Limited, England). Results were expressed in milligrams of gallic acid per kilogram of oil (Gutfinger, 1981).

\subsection{Chemical analysis of oils}

Acid value (AV) in terms of (Oleic acid \%), peroxide value (PV) in terms of $\mathrm{mEq} \mathrm{O} 2 \mathrm{~kg}^{-1}$ oil, iodine value (IV) in $\mathrm{g} \mathrm{I}_{2} 100 \mathrm{~g}^{-1}$ and saponification (specification) value (SV) in term of $\mathrm{mg}$ $\mathrm{KOH} \mathrm{g} \mathrm{g}^{-1}$ oil sample were determined according to standard methods (Official Methods of Analysis, 2010). TBA number (Thiobarbituric acid) in 
mg MDA kg-1 sample was measured according to IUPAC direct method (International Union of Pure and Applied Chemistry, 1992).

\subsection{Statistical analysis}

Treatments were distributed in a completely randomized design with three replicates. Data were subjected to the analysis of variance test (ANOVA) using the SUPERANOVA computer package (Abacus Concepts Inc, Berkeley, CA, USA; 1998). The p-value of less than 0.05 was considered statistically significant. The degree of significance was denoted as: $\mathrm{p}<0.05^{*}, \mathrm{p}<0.01^{* *}$ (Snedecor \& Cochran, 1988).

\section{$3 \quad$ Results and Discussions}

\subsection{Effect of gamma irradiation and storage time on acid value of olive oil}

The acid values (AV) in terms of percent of free fatty acid FFA (\% oleic acid) of oils obtained from olives treated at $0,1,2$ and $3 \mathrm{kGy}$ of gamma irradiation and stored at ambient temperature for 0,30 and 45 days before extraction and stored at ambient temperature for 0,6 and 12 months after extraction are presented in Table 1 . The AV of oil extracted from olives immediately after harvest (at day zero) was $1.04 \%$. The AV of olive oil was not significantly $(\mathrm{p}>0.05)$ changed by gamma irradiation, while the AV of olive oil was significantly $(\mathrm{p}<0.05)$ changed by storage time. The AV of the analyzed oils extracted immediately after irradiation at 0, 1, 2 and $3 \mathrm{kGy}$ and stored for 0,6 and 12 months ranged from $0.94 \%$ to $1.23 \%$ and did not exceed the standard limit of $2.0 \%$, indicating that these oils could be labeled as virgin olive oil quality (International Olive Council, 2015)

Data presented in Table 1 indicate that the AV of oil extracted after 30 days of harvest was $9.15 \%$. The AV of olive oil was significantly $(\mathrm{p}<0.01)$ decreased by gamma irradiation, while the AV of olive oil was not significantly $(\mathrm{p}>0.05)$ changed by storage time. The AV of the analyzed oils extracted from olive fruits stored for 30 days of irradiated olives at $0,1,2$ and $3 \mathrm{kGy}$ and stored for
0, 6 and 12 months ranged from $5.31 \%$ to $9.97 \%$ and exceed the standard limit of $3.3 \%$, indicating that these oils could not be labeled as ordinary virgin olive oil quality (International Olive Council, 2015).

The results of this study show that the AV of oil extracted after 45 days of harvest was $13.28 \%$. The AV of olive oil was significantly $(\mathrm{p}<0.01)$ decreased by gamma irradiation, while the AV of olive oil was significantly $(\mathrm{p}<0.05)$ increased by storage time. The AV of the analyzed oils extracted after 45 days of irradiated olives at 0,1 , 2 and $3 \mathrm{kGy}$ and stored for 0, 6 and 12 months ranged from $6.92 \%$ to $15.22 \%$. Oxidation of oils generates a multitude of compounds, such short chain acids, formed by the oxidation of aldehydes. Under proper harvest conditions, very little hydrolysis of triglycerides is seen. However, there are a number of bad harvest practices that lead to hydrolysis, including improper storage conditions and presence of pests or mold. Therefore, such bad practices lead to off-tasting oil. One of the primary international standards for olive oil is the level of free fatty acids that arises from hydrolysis of the triglycerides in the olives prior to processing (Blatchly et al., 2014).

\subsection{Effect of gamma irradiation and storage time on peroxide value of olive oil}

The peroxide value (PV) of oils is an important indicator of deterioration of fats. As oxidation takes place the double bonds in the unsaturated fatty acids are attacked forming peroxides. This parameter is expressed as a meq $\mathrm{O}_{2} \mathrm{~kg}^{-1}$ oil (Enujiugha, Olotu, Malomo, \& Sanni, 2012).

Table 1 shows PV in terms of meq $\mathrm{O}_{2} \mathrm{~kg}^{-1}$ of all studied samples. The PV of oil extracted from olives immediately after harvest was $3.06 \mathrm{meq}$ $\mathrm{O}_{2} \mathrm{~kg}^{-1}$ oil. The PV of olive oil was significantly $(\mathrm{p}<0.05)$ affected by gamma irradiation. The PV of oil extracted after 30 days of harvest was 4.36 meq $\mathrm{O}_{2} \mathrm{~kg}^{-1}$ oil. The PV of oil extracted after 45 days of harvest was 3.67 meq $\mathrm{O}_{2} \mathrm{~kg}^{-1}$ oil. The AV of olive oil was not significantly $(\mathrm{p}<0.05)$ affected by gamma irradiation nor by storage time. The PV of the analyzed oils extracted after 0 , 30 and 45 days of irradiated olives at $0,1,2$ 
Table 1: Effect of the extraction time and gamma irradiation on acid value (free fatty acid) (\%) and peroxide value $\left(\mathrm{mEqO}_{2} \mathrm{~kg}^{-1}\right.$ oil $)$ of olive oil

\begin{tabular}{|c|c|c|c|c|c|c|}
\hline \multicolumn{2}{|c|}{ Treatments } & Control & $1 \mathrm{kGy}$ & $2 \mathrm{kGy}$ & $3 \mathrm{kGy}$ & P-Value \\
\hline Туре & \multicolumn{6}{|c|}{ Acid value Free Fatty Acid (\%) } \\
\hline \multirow{6}{*}{0 days } & 0 months & $1.04 \pm 0.08^{a B}$ & $1.04 \pm 0.08^{a B}$ & $1.09 \pm 0.02^{a B}$ & $1.08 \pm 0.04^{a A}$ & NS \\
\hline & 6 months & $0.99 \pm 0.1^{b B}$ & $0.94 \pm 0.02^{c B}$ & $1.04 \pm 0.03^{a C}$ & $1.05 \pm 0.02^{a A}$ & 2 \\
\hline & 12 months & $1.15 \pm 0.02^{a A}$ & $1.20 \pm 0.09^{a A}$ & $1.23 \pm 0.02^{a A}$ & $0.97 \pm 0.05^{b B}$ & * \\
\hline & P-Value & $*$ & NS & $* *$ & $*$ & \\
\hline & 0 months & $9.15 \pm 0.54^{a A}$ & $8.96 \pm 0.39^{a B}$ & $7.10 \pm 0.40^{b B}$ & $5.31 \pm 0.05^{c A}$ & $* *$ \\
\hline & 6 months & $8.64 \pm 0.15^{a A}$ & $8.77 \pm 0.17^{a B}$ & $7.25 \pm 0.27^{b A B}$ & $5.31 \pm 0.17^{c A}$ & $* *$ \\
\hline \multirow{3}{*}{30 days } & 12 months & $9.76 \pm 0.86^{a A}$ & $9.97 \pm 0.56^{a A}$ & $7.96 \pm 0.44^{b A}$ & $5.36 \pm 1.35^{c A}$ & $* *$ \\
\hline & P-Value & NS & $*$ & $*$ & NS & \\
\hline & 0 months & $13.28 \pm 0.84^{a B}$ & $13.13 \pm 0.26^{a B}$ & $9.72 \pm 0.34^{b B}$ & $6.92 \pm 0.15^{c B}$ & $* *$ \\
\hline \multirow[b]{2}{*}{45 days } & 6 months & $14.52 \pm 0.15^{a A}$ & $14.94 \pm 0.58^{a A}$ & $10.38 \pm 0.19^{b A B}$ & $6.97 \pm 0.08^{c B}$ & $* *$ \\
\hline & $\begin{array}{l}12 \text { months } \\
\text { P-Value }\end{array}$ & $\begin{array}{c}14.68 \pm 0.07^{a A} \\
*\end{array}$ & $\begin{array}{c}15.22 \pm 0.39^{a A} \\
*\end{array}$ & $\begin{array}{c}11.10 \pm 0.62^{b A} \\
* *\end{array}$ & $\begin{array}{c}7.44 \pm 0.34^{c A} \\
*\end{array}$ & $* *$ \\
\hline \multicolumn{7}{|c|}{ Peroxide value $\left(\mathrm{mEqO}_{2} / \mathrm{kg}\right.$ Oil $)$} \\
\hline \multirow{4}{*}{0 days } & 0 months & $3.06 \pm 0.03^{b C}$ & $3.06 \pm 0.03^{b B}$ & $3.14 \pm 0.06^{a B}$ & $3.19 \pm 0.04^{a C}$ & * \\
\hline & 6 months & $4.05 \pm 0.12^{a B}$ & $4.51 \pm 0.51^{a A}$ & $4.39 \pm 0.20^{a A}$ & $4.32 \pm 0.12^{a B}$ & NS \\
\hline & $\begin{array}{l}12 \text { months } \\
\text { P-Value }\end{array}$ & $\begin{array}{c}4.99 \pm 0.31^{a A} \\
* *\end{array}$ & $\begin{array}{c}4.99 \pm 0.18^{a A} \\
* *\end{array}$ & $\begin{array}{c}4.68 \pm 0.27^{a A} \\
* *\end{array}$ & $\begin{array}{c}4.70 \pm 0.11^{a A} \\
* *\end{array}$ & NS \\
\hline & 0 months & $4.36 \pm 0.05^{b B}$ & $4.26 \pm 0.05^{b A}$ & $4.25 \pm 0.07^{b B}$ & $5.49 \pm 0.08^{a A}$ & $* *$ \\
\hline \multirow{4}{*}{30 days } & 6 months & $4.83 \pm 0.56^{a A B}$ & $4.09 \pm 0.45^{a A}$ & $5.03 \pm 0.60^{a A}$ & $5.11 \pm 0.46^{a A B}$ & NS \\
\hline & 12 months & $5.36 \pm 0.51^{a A}$ & $4.30 \pm 0.26^{b A}$ & $4.42 \pm 0.27 \mathrm{~b}^{A B}$ & $4.70 \pm 0.17^{b B}$ & $*$ \\
\hline & P-Value & $*$ & NS & $*$ & $*$ & \\
\hline & 0 months & $3.67 \pm 0.16^{a B}$ & $3.61 \pm 0.08^{a B}$ & $3.60 \pm 0.05^{a C}$ & $3.60 \pm 0.03^{a C}$ & NS \\
\hline \multirow{3}{*}{45 days } & 6 months & $4.37 \pm 0.09^{a A}$ & $4.39 \pm 0.04^{a A}$ & $4.39 \pm 0.13^{a A}$ & $4.37 \pm 0.07^{a A}$ & NS \\
\hline & 12 months & $4.50 \pm 0.13^{a A}$ & $4.29 \pm 0.60^{a A B}$ & $4.09 \pm 0.17^{a B}$ & $4.05 \pm 0.20^{a B}$ & NS \\
\hline & P-Value & $3.06 \pm 0.03^{b C}$ & $3.06 \pm 0.03^{b B}$ & $3.14 \pm 0.06^{a B}$ & $3.19 \pm 0.04^{a C}$ & $*$ \\
\hline
\end{tabular}

$a b c$ Mean values in the same column not sharing a superscript are significantly different

$A B C$ Mean values in the same row not sharing a superscript are significantly different.

NS: not significant.

* Significant at $\mathrm{p}<0.05$.

** Significant at $\mathrm{p}<0.01$

and $3 \mathrm{kGy}$ and stored for 0,6 and 12 months ranged from 3.06 to 5.49 meq $\mathrm{O}_{2} \mathrm{~kg}^{-1}$ oil (Table 1) being lower than the maximum value (20 meq $\mathrm{O}_{2} \mathrm{~kg}^{-1}$ oil), which is accepted as the limit for extra-quality virgin olive oil category (International Olive Council, 2015). The challenge is to produce high quality olive oils. According to the literature, hydroperoxides, the initial products of oxidation, are comparatively unstable, are a very sensitive indicator of the early stages of oxidative deterioration and a good guide to the evaluation of olive oil quality (Vekiari et al., 2007). Onyeike and Acheru (2002) reported the peroxide value of castor, coconut, diakanut, groundnut, melon, bean and palm kernel seed oil to be 22.7, 40.0, 40.0, 20.0, 21.3, 23.3 and $20.0 \mathrm{mg} \mathrm{g}^{-1}$ of sample, respectively. These values were generally higher than those reported by Okogeri and Okoro (2014) who reported the ranges of peroxide values of unadulterated palm kernel oil to be 3.35, 16.00 and 2.07- 6.80 meq $\mathrm{kg}^{-1}$, respectively that are also higher than the values reported for groundnut oil (Yusuf, Olaniyan, Atanda, \& Sulieman, 2014). Abiodun, Akinoso, Olosunde, Adegbite, and Omolola (2014) determined a PV of $11.0 \mathrm{mg}$ $\mathrm{g}^{-1}$ for Thaumatococcus danielli, which in a typ- 
ical fruit plant. The difference in the value must have resulted from the different methods used for determination as well as the variation in the species. Regarding the effect of gamma radiation on the peroxide values, present results are in general agreement with those obtained from pumpkin (El-Aziz \& El-Kalek, 2011), and sesame oil (Al-Bachir, 2016). It should be noted that the PV characterizes the quantity of peroxides formed in the oils are as intermediates of oxidative reactions under irradiation and high temperatures (Uquiche, Jerez, \& Ortiz, 2008).

\subsection{Effect of gamma irradiation and storage period on TBA value of olive oil}

The thiobarbituric acid value (TBA) of oil extracted from olive fruits stored for 0,30 and 45 days were $0.025,0.025$ and $0.026 \mathrm{mg}$ MDA kg-1 oil, respectively (Table 2). The TBA of olive oil extracted from olive fruits stored for 0 and 45 days was not significantly $(\mathrm{p}>0.05)$ affected by gamma irradiation, while the TBA of olive oil extracted from olives stored for 30 days was significantly $(\mathrm{p}>0.01)$ changed by gamma irradiation. Also, the TBA value of olive oil extracted from olives immediately after harvest (at day zero) did not significantly $(\mathrm{p}>40.05)$ changed by storage time, while the TBA of olive oil extracted from olives stored for 30 and 45 days was significantly $(\mathrm{p}<0.01)$ changes with storage time. The TBA of the analyzed oils extracted from olives stored for 0,30 and 45 days of irradiated olives at 0,1 , 2 and $3 \mathrm{kGy}$ and stored for 0,6 and 12 months ranged from 0.022 to $0.027 \mathrm{mg} \mathrm{MDA} \mathrm{kg} \mathrm{kg}^{-1}$ oil (Table 2). Some significant changes were observed during the creation of TBA in olive oil due to irradiation and storage, but the changes were within the standard limits given by the International Olive Council (International Olive Council, 2015). Our results, related to the TBA analyses are consistent with previous reports, which also reveal a slight difference in TBA value due to irradiation at 1, 2 and $3 \mathrm{kGy}$, and storage for 12 months of almond (Al-Bachir \& Zeinou, 2014), pistachios (Al-Bachir, 2015b), and peanuts (AlBachir, 2015a).

\subsection{Effect of gamma irradiation and storage period on phenolic content of olive oil}

It has been noted that phenols and polyphenols are substances with natural antioxidant properties and their presence in olive oils has been associated to their general quality, improving storability, nutritional value and sensorial properties (Fernandes-Silva, Gouveia, Vasconcelos, Ferreira, \& Villalobos, 2013). The concentration of total phenols of olive oil extracted from irradiated and non-irradiated fruits at different periods of extraction and storage time are presented in Table 2. The initial concentration of total phenolics in the olive oil extracted from olive fruits stored for 0, 30 and 45 days were $314.71,194.53$ and $154.43 \mathrm{mg}$ gallic acid $\mathrm{kg}^{-1}$ oils, respectively. The phenolic content of oil extracted from olive fruits stored for 0,30 and 45 days was significantly $(\mathrm{p}<0.05)$ changed by gamma irradiation and storage. This data indicate that gamma irradiation is capable of affecting the phenolic composition in olive oil. In general, the concentration of total phenolics in the olive oil decreased with increasing irradiation dosed and storage time. Storage time has a much greater influence on reducing the phenolic contents in olive oil comparing to the applied irradiation doses.

In agreement with our study, Antonio et al. (2011) reported that storage time (up to 60 days) had a much higher influence on the variation, with irradiation (up to $0.54 \mathrm{kGy}$ ) being a minor contributor to change the phenolic content in chestnut during storage.

Nothing was reported on the effect of gamma irradiation on this property of olive oil. However, the effect of the irradiation treatments on phenolic contents was reported for other plants and spices. Our finding was in agreement with that of Koseki et al. (2002) who reported that gamma irradiation, up to $30 \mathrm{kGy}$, decreased total phenolics in dehydrated rosemary. Gamma irradiation treatment have been shown to either increase or decrease the total phenolics content of plant materials, which is dependent on the dose delivered and the raw materials used. Khattak, Simpson, and Ihasnullah (2009) reported that gamma irradiation at dosage levels of $1,2,4$ 
Table 2: Effect of gamma irradiation and storage period on TBA value (mg MDA kg-1 oil) and total phenolics (mg gallic acid $\mathrm{kg}^{-1}$ oil) of olive oil

\begin{tabular}{|c|c|c|c|c|c|c|}
\hline \multicolumn{2}{|c|}{ Treatments } & Control & 1 kGy & 2 kGy & 3 kGy & P-Value \\
\hline Type & \multicolumn{6}{|c|}{ TBA value (mg MDA/kg Oil) } \\
\hline \multirow{5}{*}{0 days } & 6 months & $0.022 \pm 0.001^{a A}$ & $0.023 \pm 0.001^{a B}$ & $0.023 \pm 0.001^{a A}$ & $0.023 \pm 0.001^{a B}$ & NS \\
\hline & 12 months & $0.026 \pm 0.001^{a A}$ & $0.024 \pm 0.001^{a A}$ & $0.023 \pm 0.001^{a A}$ & $0.024 \pm 0.001^{a A}$ & NS \\
\hline & P-Value & NS & $*$ & NS & $*$ & \\
\hline & 0 months & $0.025 \pm 0.001^{a C}$ & $0.025 \pm 0.001^{a A}$ & $0.026 \pm 0.001^{a A}$ & $0.025 \pm 0.001^{a A}$ & $* *$ \\
\hline & 6 months & $0.022 \pm 0.001^{b B}$ & $0.023 \pm 0.001^{a A B}$ & $0.023 \pm 0.001^{a B}$ & $0.024 \pm 0.001^{a B}$ & $* *$ \\
\hline \multirow[t]{3}{*}{30 days } & 12 months & $0.023 \pm 0.001^{b A}$ & $0.023 \pm 0.001^{a B}$ & $0.023 \pm 0.001^{a B}$ & $0.024 \pm 0.001^{a B}$ & NS \\
\hline & P-Value & $* *$ & NS & $* *$ & $* *$ & \\
\hline & 0 months & $0.026 \pm 0.01^{a A}$ & $0.024 \pm 0.001^{a A}$ & $0.027 \pm 0.001^{a A}$ & $0.024 \pm 0.001^{a B}$ & NS \\
\hline \multirow{3}{*}{45 days } & 6 months & $0.023 \pm 0.01^{a B}$ & $0.024 \pm 0.001^{a A}$ & $0.024 \pm 0.001^{a A}$ & $0.024 \pm 0.001^{a A}$ & NS \\
\hline & 12 months & $0.024 \pm 0.01^{b C}$ & $0.025 \pm 0.001^{a b A}$ & $0.026 \pm 0.001^{a A}$ & $0.026 \pm 0.001^{a A B}$ & $*$ \\
\hline & P-Value & $* *$ & NS & NS & $*$ & \\
\hline \multicolumn{7}{|c|}{ Total phenolics (mg gallic acid/kg Oil) } \\
\hline \multirow{4}{*}{0 days } & 6 months & $281.56 \pm 3.12^{a A}$ & $276.32 \pm 5.28^{a A}$ & $255.24 \pm 13.18^{b B}$ & $258.21 \pm 11.67^{b B}$ & $*$ \\
\hline & 12 months & $165.72 \pm 3.43^{a B}$ & $164.50 \pm 4.70^{a B}$ & $164.24 \pm 3.49^{a C}$ & $171.15 \pm 3.55^{a C}$ & NS \\
\hline & P-Value & $* *$ & $* *$ & $* *$ & $* *$ & \\
\hline & 0 months & $194.53 \pm 5.56^{a A}$ & $192.16 \pm 1.97^{a A}$ & $184.26 \pm 4.48^{b A}$ & $179.35 \pm 2.46^{b A}$ & $* *$ \\
\hline \multirow{4}{*}{30 days } & 6 months & $168.47 \pm 1.77^{a B}$ & $164.77 \pm 1.37^{a b B}$ & $162.90 \pm 3.66^{b B}$ & $160.04 \pm 3.49^{b B}$ & $*$ \\
\hline & 12 months & $136.56 \pm 3.11^{a C}$ & $139.53 \pm 0.71^{a C}$ & $136.72 \pm 1.51^{a C}$ & $138.22 \pm 2.46^{a C}$ & NS \\
\hline & P-Value & $* *$ & $* *$ & $* *$ & $* *$ & \\
\hline & 0 months & $154.43 \pm 4.56^{a A}$ & $151.68 \pm 4.26^{a A}$ & $150.38 \pm 0.90^{a b A}$ & $145.04 \pm 0.60^{b A}$ & $*$ \\
\hline \multirow{3}{*}{45 days } & 6 months & $143.88 \pm 3.54^{a B}$ & $138.21 \pm 3.18^{b B}$ & $133.10 \pm 2.74^{b c B}$ & $138.72 \pm 1.69^{a b B}$ & $*$ \\
\hline & 12 months & $121.62 \pm 1.56^{a b C}$ & $123.29 \pm 1.48^{a C}$ & $119.68 \pm 1.37^{b C}$ & $120.12 \pm 1.70^{b C}$ & $*$ \\
\hline & P-Value & $* *$ & $* *$ & $* *$ & $* *$ & \\
\hline
\end{tabular}

$a b c$ Mean values in the same column not sharing a superscript are significantly different.

$A B C$ Mean values in the same row not sharing a superscript are significantly different.

NS: not significant.

* Significant at $\mathrm{p}<0.05$.

** Significant at $\mathrm{p}<0.01$

and $6 \mathrm{kGy}$ increased the yield of total phenolics in Nelumbo nucifera rhizome. In contrast to this results, it has been found that gamma irradiation with doses of $5,10,15,20$ and 25 kGy did not have any significant change in the total phenolic contents of olive leaves (Aouidi, Ayari, Ferhi, Roussos, \& Hamdi, 2011). When compared with respective control seed materials, irradiation (with 2, 4 and $6 \mathrm{kGy}$ ) significantly $(\mathrm{p}<0.05)$ increased the total phenolic contents. This might be due to the increased extractability of phenolics by depolymerisation and dissolution of cell wall polysaccharides after irradiation (Bhat, Sridhar, \& Tomita-Yokotani, 2007).

\subsection{Effect of gamma irradiation and storage time on iodine value of olive oil}

The iodine value (IV) (degree of un-saturation) of olive oils obtained from olives stored at ambient temperature for 0,30 and 45 days were found to be $93.38,88.44$ and $83.89 \mathrm{~g} \mathrm{I}_{2} 100 \mathrm{~g}^{-1}$ oil, respectively (Table 3 ). The values support that the oil is unsaturated but not highly. The IV of olive oil was significantly $(\mathrm{p}<0.05)$ changed by gamma irradiation and storage time. In general, the doses of gamma irradiation used (1,2 and 3 $\mathrm{kGy}$ ) and storage time of oils (6 and 12 moths) significantly $(\mathrm{p}<0.05)$ decreased the iodine value of olive oil. The decrease in IV upon irradiation 
Effect of storage and irradiation on olive oil $\mid 85$

Table 3: Effect of gamma irradiation and storage period on iodine number $\left(\mathrm{g} \mathrm{I}_{2} 100 \mathrm{~g}^{-1}\right.$ oil $)$ and saponification value (mg KOH. $\mathrm{g}^{-1}$ oil) of olive oil

\begin{tabular}{|c|c|c|c|c|c|c|}
\hline \multicolumn{2}{|c|}{ Treatments } & Control & $1 \mathrm{kGy}$ & $2 \mathrm{kGy}$ & $3 \mathrm{kGy}$ & P-Value \\
\hline Type & \multicolumn{6}{|c|}{ Iodine number $\left(\mathrm{g} \mathrm{I}_{2} 100 \mathrm{~g}^{-1} \mathrm{Oil}\right)$} \\
\hline \multirow{4}{*}{0 days } & 0 months & $93.38 \pm 0.46^{a A}$ & $90.33 \pm 4.30^{a A}$ & $90.26 \pm 1.92^{a A}$ & $90.75 \pm 0.15^{a A}$ & NS \\
\hline & 6 months & $82.43 \pm 1.41^{a b B}$ & $83.63 \pm 0.76^{a B}$ & $81.80 \pm 0.72^{a b C}$ & $80.80 \pm 0.99^{b C}$ & $*$ \\
\hline & $\begin{array}{l}12 \text { months } \\
\text { P-Value }\end{array}$ & $\begin{array}{c}84.17 \pm 1.65^{a B} \\
* *\end{array}$ & $\begin{array}{c}84.32 \pm 0.59^{a B} \\
*\end{array}$ & $\begin{array}{c}84.30 \pm 0.23^{a B} \\
* *\end{array}$ & $\begin{array}{c}83.47 \pm 0.35^{a B} \\
* *\end{array}$ & NS \\
\hline & 0 months & $88.44 \pm 1.70^{a A}$ & $84.40 \pm 1.95^{a b A B}$ & $80.88 \pm 6.03^{b A}$ & $79.87 \pm 0.92^{b B}$ & $*$ \\
\hline \multirow{3}{*}{30 days } & 6 months & $84.65 \pm 0.75^{b B}$ & $85.14 \pm 1.57^{b A}$ & $84.41 \pm 0.30^{b A}$ & $87.40 \pm 1.27^{a A}$ & * \\
\hline & $\begin{array}{l}12 \text { months } \\
\text { P-Value }\end{array}$ & $\begin{array}{c}81.58 \pm 1.94^{a B} \\
* *\end{array}$ & $\begin{array}{c}79.88 \pm 3.36^{a B} \\
*\end{array}$ & $\begin{array}{c}80.30 \pm 1.17^{a A} \\
\text { NS }\end{array}$ & $\begin{array}{c}80.33 \pm 1.06^{a B} \\
* *\end{array}$ & NS \\
\hline & 0 months & $83.89 \pm 0.46^{a A B}$ & $83.71 \pm 1.37^{a A B}$ & $81.94 \pm 1.55^{a b B}$ & $80.61 \pm 1.02^{b B}$ & * \\
\hline \multirow{3}{*}{45 days } & 6 months & $86.78 \pm 1.11^{a A}$ & $86.56 \pm 0.82^{a A}$ & $83.90 \pm 1.87^{b A B}$ & $83.57 \pm 1.08^{a B}$ & ** \\
\hline & 12 months & $82.80 \pm 2.49^{b B}$ & $81.38 \pm 2.69^{b B}$ & $85.99 \pm 1.56^{b A}$ & $91.87 \pm 2.94^{a A}$ & $* *$ \\
\hline & P-Value & $*$ & $*$ & $* *$ & $* *$ & \\
\hline \multicolumn{7}{|c|}{ Saponification value (mg KOH. $\mathrm{g}^{-1}$ Oil) } \\
\hline \multirow{4}{*}{0 days } & 0 months & $194.88 \pm 1.08^{a B B}$ & $196.74 \pm 1.29^{a A}$ & $197.06 \pm 0.76^{a A}$ & $195.66 \pm 2.03^{a A}$ & NS \\
\hline & 6 months & $193.38 \pm 0.46^{a B}$ & $192.43 \pm 1.34^{a B}$ & $191.60 \pm 0.86^{a B}$ & $192.93 \pm 1.28^{a A}$ & NS \\
\hline & $\begin{array}{l}12 \text { months } \\
\text { P-Value }\end{array}$ & $\begin{array}{c}196.07 \pm 0.79^{a A} \\
*\end{array}$ & $\begin{array}{c}195.55 \pm 0.97^{a b A} \\
*\end{array}$ & $\begin{array}{c}195.79 \pm 1.09^{b A} \\
* *\end{array}$ & $\begin{array}{c}194.79 \pm 1.03^{a b A} \\
\text { NS }\end{array}$ & NS \\
\hline & 0 months & $195.03 \pm 1.20^{a A}$ & $194.28 \pm 1.85^{a A}$ & $194.23 \pm 0.37^{a A}$ & $191.57 \pm 0.98^{b A}$ & $*$ \\
\hline \multirow{3}{*}{30 days } & 6 months & $192.69 \pm 1.27^{a B}$ & $193.44 \pm 1.04^{a A}$ & $193.88 \pm 1.70^{a A}$ & $191.85 \pm 1.44^{a A}$ & NS \\
\hline & 12 months & $\begin{array}{c}194.99 \pm 0.89^{a A} \\
*\end{array}$ & $194.88 \pm 0.65^{a b A}$ & $195.14 \pm 0.26^{a b A}$ & $194.29 \pm 0.59^{b B}$ & NS \\
\hline & $\begin{array}{l}\text { P-Value } \\
0 \text { months }\end{array}$ & $197.32 \pm 1.62^{a A}$ & $196.37 \pm 2.52^{a A}$ & $194.76 \pm 1.01^{a A}$ & $194.50 \pm 1.99^{a A}$ & NS \\
\hline \multirow{3}{*}{45 days } & 6 months & $193.74 \pm 0.57^{a B}$ & $194.00 \pm 0.51^{a A}$ & $193.90 \pm 0.91^{a A}$ & $193.93 \pm 0.54^{a A}$ & NS \\
\hline & 12 months & $194.13 \pm 0.48^{a B}$ & $193.70 \pm 0.31^{a A}$ & $193.80 \pm 0.38^{a A}$ & $194.43 \pm 0.67^{a A}$ & NS \\
\hline & P-Value & $* *$ & NS & NS & NS & \\
\hline
\end{tabular}

$a b c$ Mean values in the same column not sharing a superscript are significantly different.

$A B C$ Mean values in the same row not sharing a superscript are significantly different.

NS: not significant.

* Significant at $\mathrm{p}<0.05$

** Significant at $\mathrm{p}<0.01$.

or storage could be attributed to some loss in the un- saturated fatty acids of olive oil by irradiation and the formation of peroxide compounds. These results are in agreement with those obtained by several investigators who reported a decrease in the IV of soybean sesame, peanut oil upon irradiation (Afify, Rashed, Ebtesam, \& ElBeltagi, 2013). Radiation probably broke some double bonds and induced oxidation processes in fatty acids resulted in its saturation (Anjum, Anwar, Jamil, \& Iqbal, 2006). These results also agree with other studies, which found that, the unirradiated samples had highest iodine values, suggesting saturation of oils as a results of irradiation (El-Aziz \& El-Kalek, 2011).

\subsection{Effect of gamma irradiation and storage period on saponification value of olive oil}

Table 3 shows the saponification value (SV) data reported as mean value of oils obtained from olive fruits treated at 0, 1, 2 and $3 \mathrm{kGy}$ of gamma irradiation and stored at ambient temperature for 0 , 30 and 45 days before extraction and stored oil at ambient temperature for 0, 6 and 12 months after extraction. Initial SV for olive oil obtained from fruits stored at ambient temperature for 0, 30 and 45 days were 194.88, 195.03 and $197.32 \mathrm{mg} \mathrm{KOH} \mathrm{g}^{-1}$ oil, respectively. The 
applied irradiation doses did not cause any significant change in the SV of olive oils. The current study demonstrated that storage time caused significant $(p<0.05)$ changes in the SV of olive oil obtained from non-irradiated olives and stored at ambient temperature for 0,30 or 45 days. The $\mathrm{SV}$ of the analyzed oils extracted after 0,30 and 45 days of irradiated olives at $0,1,2$ and $3 \mathrm{kGy}$ and stored for 0,6 and 12 months ranged from 191.57 to $197.32 \mathrm{mg} \mathrm{KOH} \mathrm{g}{ }^{-1}$ oil. These values fall within the recommended Codex for virgin olive oil (Codex Alimentarius, 2003). Regarding the effects of gamma radiation on the SV of olive oil, results of this study were in contrast with a previous study, where SV of irradiated pistachio was increased upon irradiation (Al-Bachir, 2015b). Whereas, a decrease in SV was found in gamma irradiated almonds (Al-Bachir \& Zeinou, 2014). Therefore, it can be concluded that the effect of gamma irradiation on $\mathrm{SV}$ of oils is affected by plant species.

\section{Conclusion}

The results of this study demonstrated that the acid values of the oil extracted immediately after harvest were lower than $2 \%$ which is the limit set for "virgin olive oil quality". While the AV of oil extracted from olive fruit stored for 30 days exceed the standard limit of $3.3 \%$, indicating that these oils could not be labeled as ordinary virgin olive oil quality (International Olive Council, 2015). The AV of olive oil was significantly $(\mathrm{p}<0.05)$ decreased by gamma irradiation. Also, phenol content in olive oil was significantly $(\mathrm{p}<0.05)$ decreased by gamma irradiation and storage time.

\section{Acknowledgements}

The author wish to express deep appreciation to the Director General of the Atomic Energy Commission of Syria (AECS) and the staff of the division of food irradiation.

\section{References}

Abiodun, O. A., Akinoso, R., Olosunde, O. O., Adegbite, J. A., \& Omolola, O. A. (2014).
Nutritional quality and essential oil compositions of thaumatococcus danielli (benn.) tissue and seed. Food Chemistry, 160, 286291. doi:10.1016/j.foodchem.2014.03.114

Afify, A. M. R., Rashed, M. M., Ebtesam, A. M., \& El-Beltagi, H. S. (2013). Effect of gamma radiation on the lipid profiles of soybean, peanut and sesame seed oils. Grasas $Y$ Aceites, 64 (4), 356-368. doi:10.3989/gya. 119712

Anjum, F., Anwar, F., Jamil, A., \& Iqbal, M. (2006). Microwave roasting effects on the physico-chemical composition and oxidative stability of sunflower seed oil. Journal Of The American Oil Chemists Society, 83(9), 777-784. doi:10.1007/s11746006-5014-1

Antonio, A. L., Ramalhosa, E., Botelho, M. L., Quintana, B., Trigo, M. J., Ferreira, A., \& Bento, A. (2011). Irradiação gama de castanhas calibradas provenientes de uma unidade industrial: cor e textura. Universidade de Évora. Retrieved from http://hdl. handle.net/10198/7292

Aouidi, F., Ayari, S., Ferhi, H., Roussos, S., \& Hamdi, M. (2011). Gamma irradiation of air-dried olive leaves: effective decontamination and impact on the antioxidative properties and on phenolic compounds. Food Chemistry, 127(3), 1105-1113. doi:10. 1016/j.foodchem.2011.01.109

Artajo, L. S., Romero, M. P., Morello, J. R., \& Motilva, M. J. (2006). Enrichment of refined olive oil with phenolic compounds: evaluation of their antioxidant activity and their effect on the bitter index. Journal Of Agricultural And Food Chemistry, 54(16), 6079-6088. doi:10.1021/jf060874q

El-Aziz, A. B. \& El-Kalek, H. H. (2011). Antimicrobial proteins and oil seeds from pumpkin (cucurbita moschata). Nature and Science, 9(3), 105-119. doi:10.7537/marsnsj090311. 16

Al-Bachir, M. \& Zeinou, R. (2014). Effect of gamma irradiation on the microbial load, chemical and sensory properties of goat meat. Acta Alimentaria, 43(2), 264-272. doi:10.1556/AAlim.43.2014.2.10

Al-Bachir, M. (2015a). Quality characteristics of oil extracted from gamma irradiated 
peanut (arachis hypogea 1.) Radiation Physics And Chemistry, 106, 56-60. doi:10. 1016/j.radphyschem.2014.06.026

Al-Bachir, M. (2015b). Studies on the physicochemical characteristics of oil extracted from gamma irradiated pistachio (pistacia vera l.) Food Chemistry, 167, 175-179. doi:10.1016/j.foodchem.2014.06.020

Al-Bachir, M. (2016). Some microbial, chemical and sensorial properties of gamma irradiated sesame (sesamum indicum 1.) seeds. Food Chemistry, 197(A), 191-197. doi:10. 1016/j.foodchem.2015.10.094

Baiano, A., Terracone, C., Viggiani, I., \& Del Nobile, M. A. (2014). Changes produced in extra-virgin olive oils from cv. coratina during a prolonged storage treatment. Czech Journal Of Food Sciences, 32(1), 1-9.

Bhat, R., Sridhar, K., \& Tomita-Yokotani, K. (2007). Effect of ionizing radiation on antinutritional features of velvet bean seeds (mucuna pruriens). 103, 860-866.

Blatchly, R. A., Delen, Z., \& O'Hara, P. B. (2014). Making sense of olive oil: simple experiments to connect sensory observations with the underlying chemistry. Journal Of Chemical Education, 91 (10), 16231630. doi:10.1021/ed300557r

Cecchi, T., Passamonti, P., \& Cecchi, P. (2010). Study of the quality of extra virgin olive oil stored in pet bottles with or without an oxygen scavenger. Food Chemistry, 120(3), 730-735. doi:10.1016/j.foodchem.2009.11. 001

Codex Alimentarius. (2003). Codex standard for olive oils and olive pomace oils (2003): Codex Stan 33- 1981 (Rev. 2 - 2003) p, 1-8. Retrieved from https://static.oliveoiltimes. com/library/codex-alimentarius-olive- oilstandard.pdf

Enujiugha, V., Olotu, I., Malomo, S., \& Sanni, T. (2012). The effect of r-irradiation and cooking on the physicochemical properties of african oil bean seed (pentaclethra macrophylla benth) and its oil extract. Journal of Food Research, 1(2), 189. doi:10.5539/ jfr.v1n2p189

Fernandes-Silva, A. A., Gouveia, J. B., Vasconcelos, P., Ferreira, T. C., \& Villalobos, F. J. (2013). Effect of different irrigation regimes on the quality attributes of monovarietal virgin olive oil from cv. "cobrançosa". Grasas $Y$ Aceites, 64(1), 41-49.

Garcia-Gonzalez, D. L. \& Aparicio, R. (2010). Research in olive oil: challenges for the near future. Journal Of Agricultural And Food Chemistry, 58(24), 12569-12577. doi:10 . 1021/jf102735n

Gutfinger, T. (1981). Polyphenols in olive oils. Journal Of The American Oil Chemists Society, 58(11), 966-968. doi:10 . 1007/ BF02659771

Hong, S. I., Kim, J. Y., Cho, S. Y., \& Park, H. J. (2010). The effect of gamma irradiation on oleic acid in methyl oleate and food. Food Chemistry, 121(1), 93-97. doi:10.1016/j. foodchem.2009.12.008

International Olive Council. (2015). Trade standard applying to olive oils and olive pomace oils. COI/ T.15/NC No 3/Rev. 9 June, 2015.

International Union of Pure and Applied Chemistry. (1992). Determination of 2-thiobarbituric acid Value: Direct Method.Vol.61, №6, PP.1165-1170. Standard Methods for the Analysis of Oils, Fats and Derivates, 7th ed. (Paquot C; Hautffenne A, eds). International Union of Pure and Applied Chemistry, Blackwell Scientific Publications Inc., Oxford, UK.

Jenisová, Z., Branisa, J., Jomová, K., \& Porubská, M. (2014). Variations of some nutrition values of olive oil by household using. The Journal of Microbiology, Biotechnology and Food Sciences, 3, 221224. Retrieved from http://www.jmbfs . org / 62_jmbfs_jenisova_2014_fs / ?issue_id = 3039\&article_id $=19$

Khattak, K. F., Simpson, T. J., \& Ihasnullah. (2009). Effect of gamma irradiation on the microbial load, nutrient composition and free radical scavenging activity of nelumbo nucifera rhizome. Radiation Physics And Chemistry, 78(3), 206-212. doi:10.1016/j. radphyschem.2008.11.001

Koseki, P. M., Villavicencio, A. L. C. H., Brito, M. S., Nahme, L. C., Sebastiao, K. I., Rela, P. R., .. Freitas, P. C. D. (2002). Effects of irradiation in medicinal and eatable herbs. Radiation Physics And Chemistry, 
63(3-6), 681-684. 12th International Meeting on Radiation Processing (IMRP-12), AVIGNON, FRANCE, MAR 25-30, 2001. doi:10.1016/S0969-806X(01)00658-2

Official Methods of Analysis. (2010). 15th edn. Association of Official Analytical Chemists. Washington, D.C.

Okogeri, O. \& Okoro, B. (2014). Storage stability and sensory attributes of crude palm oil adulterated with red dye. European Journal of Agriculture and Forestry Research, 2(1), 10-17.

Onyeike, E. N. \& Acheru, G. N. (2002). Chemical composition of selected nigerian oil seeds and physicochemical properties of the oil extracts. Food Chemistry, 77(4), 431-437. doi:10.1016/S0308-8146(01)00377-6

Sadecka, J. (2010). Influence of two sterilisation ways, gamma-irradiation and heat treatment, on the volatiles of black pepper (piper nigrum 1.) Czech Journal Of Food Sciences, 28(1), 44-52.

Snedecor, G. \& Cochran, W. (1988). Statistical methods. (p. 221). Aiwa: The Iowa State University Press.

Uquiche, E., Jerez, M., \& Ortiz, J. (2008). Effect of pretreatment with microwaves on mechanical extraction yield and quality of vegetable oil from chilean hazelnuts (gevuina avellana mol). Innovative Food Science 85 Emerging Technologies, 9(4), 495500. doi:10.1016/j.ifset.2008.05.004

Vekiari, S. A., Papadopoullou, P., \& Kiritsakis, A. (2007). Effects of processing methods and commercial storage conditions on the extra virgin olive oil quality indexes. Grasas $Y$ Aceites, 58(3), 237-242.

Yusuf, K. A., Olaniyan, A. M., Atanda, E. O., \& Sulieman, I. A. (2014). Effects of heating temperature and seed condition on the yield and quality of mechanically expressed groundnut oil. International Journal of Technology Enhancements and Merging Engineering Research, 2, 73-78. 